\title{
CAUSES OF SCHOOL FAILURES DURING STUDIES IN THE OPINION OF TIE STUDENTS FROM THE PEDAGOGICAL UNIVERSITY OF CRACOW
}

\author{
Henryk Noga \\ Pedagogical University in Cracow, Poland \\ Jana Depešová \\ Univerzita Konštantína Filozofa v Nitre, Slovakia \\ Aleksandra Knych \\ Univerzita Konštantína Filozofa v Nitre, Slovakia
}

\begin{abstract}
European Union considers school failure as one of the greatest challenges for the education systems in the unifying Europe. What seems to be essential when considering the problem of educational failure is the question of reasons for lack of success in learning performance. This knowledge may help eliminate some factors and find a solution. The research presented in this paper shows the most important factors determining learning failures at collage in the opinion of TIE students of Pedagogical University in Cracow.

Keywords: learning failures, determinants of learning failures, TIE students.
\end{abstract}

\section{Introduction}

European Community authorities dealing with education consider school failures as a major educational challenge in the uniting Europe. This problem belongs to the substantial research areas of didactics (which looks at various aspects of effectiveness in education (DeMarie \& Aloise-Youg, 2003; Jankowska, 2014; Karpińska, 2010; Prauzer \& Ptak, 2014).

Civilization changes and resulting from them educational approaches as well as inequality in the level of education in many countries underscore the need for deep reflection on the determinants of this phenomena, permanently associated with the school activity, but also many other institutions supporting the learning process. Knowing the source of failure, one can search for countermeasures and fix the educational process. Authors who dealt with the analysis of school failures, analyze the complexity of their causes, some concentrating mostly on social and economic factors, others pointing mostly at biological and psychological components or pedagogical factors. Each of these approaches has its supporters and opponents. It should be noticed that each case is individual and should be treated individually from different perspectives (Karpińska, 2011; Niemierko, 2007; Noga, 2006). 


\section{Social and economic status of a family and school failures}

One can find many analysis of social and economic conditions that affects student performance at school. The causes of the socio-economic character include the financial state of a family that influence both - the family environment and functioning outside the school (Kupisiewicz, 1995). Researchers trace the source of poor progress of students in the terms of these conditions (Ptak \& Prauzer, 2013; Pytel \& Jaracz, 2012; Pytel, 2011). Mainly paying attention to the number of children in the family, family structure, material and housing conditions, atmosphere at home, interest in children, parental attitude, their educational level, any pathologies (Noga, 2015; Mastalerz \& Gałazka, 2006; Noddings, 2006).

Housing conditions - an important factor of the family environment is its financial status, among others: income per family member, the apartment size, equipment and other goods (kitchen appliances, TV, computer, etc.) and number of people living together. However, poor material conditions are not always the cause of school failures. This can cause problems when other disadvantageous components of the family environment occur.

Shortage of care activities of parents, parental attitude - studies in Poland and other countries show the unfavorable structure of the factors that cause slowdown of mental development of children and decrease their school achievements. These are: faulty parental attitude, inadequate family relationships, the pathological nature of a family, incorrect and inadequate social and material conditions.

The education level of parents - parent's education results in cultural level of the family. Parents that are not educated well and with lower level of education may not be able to provide educational support for their children. Pupils with learning difficulties may not count on their parents when it comes to helping them with homework due to parents low level of education and low level of educational aspirations.

The atmosphere of family life - the atmosphere specify the nature of relations between parents and may indicate some symptoms of the pathology affecting the decrease in the functioning of the student.

\section{Biological and psychological conditions}

Biological and psychological conditions are these related to the individual. Sometimes, the term "bio-psychological" is used to indicate the existence of conditions within biological and psychological factors. Below are some of these factors. 
Motivational and emotional factors - some emotional disorders, lack of willingness, ambition to learn, inability to concentrate, lack of faith in themselves and their abilities (Jankowska, 2014).

Nervous system disorders - emotional instability, aggression or apathy, lack of patience at work, some neurotic disorders as well depressive states (Kupisiewicz, 1995).

Health state - health is a factor that may hinder learning. One of the important causes of delays in learning are frequent illnesses, causing absences of students and backlogs.

\section{Pedagogical conditions}

Pedagogical conditions are these related to school, eg. organization of a school, teacher's attitude towards children, methods used in teaching process, available resources (materials, computers, etc.), atmosphere in the classroom (Knych, 2015).

Among these elements, organizational factor can be a barrier or didactic can be described as:

Often a stiff school system meets the assertion that the source of the causes of learning difficulties lie in the school system, which provides pupils with insurmountable barrier, and is not suited to their capabilities (Karpińska, 2010).

Organizational and material conditions of a school - achieving a satisfactory outcome is also hampered by poor equipment and not enough (or inappropriate) teaching aids within schools. This is quite a common problem for public schools in Poland and it is related to underinvestment in education system (Denek, 2002).

The attitude of a teacher - in some of the studies authors trace the causes of failures in the attitude of a teacher. Attitude is a very important pedagogical that may determine the efficiency of methodical approach. When a teacher respects pupils, is open to their ideas, has a friendly attitude towards them - pupils feel secure and willing to share their thoughts. Such attitude boosts children's activity on lessons and their motivation, which is very important in the learning process. On the other hand inappropriate attitude of a teacher can lead to reluctance towards not only a teacher, but the subject he/she runs. This can result in students experiencing setbacks when it comes to school activity.

\section{Students opinions on the causes of school failures}

Previous studies on causes of school failures show complexity and many types of reasons (Kupisiewicz, 1995). In this research the survey was carried out. Questionnaires were filled in by third year and first year students of 
Technical and Informatics Education (TIE) at Pedagogical University of Cracow. One of the questions asked was: "What primarily affects the failure in college in your opinion?" Next, 13 possible answers were given to choose. Only in 4 cases, students gave a different reason, which they wrote in the column "other". The distribution of answers given is presented in the tab. 1. and fig. 1. below. Most students as the main cause of failure in college indicated inadequate preparation of high school (low status of a school). $42.3 \%$ of the first year students and every fourth student of the third year $(25 \%)$ gives such reason. Another important determinant of problems in collage according to first year TIE students is choosing the wrong field of study - $15.3 \%$ pointed at this reason. Next the most important factor is lack of determination (motivation), and this element was indicated by $11.5 \%$ of first year students. According to first year students other factors do not determine learning failures (only one person or none, pointed at these elements). These are: financial difficulties, poor health, overload of learning material, lack of planning work and learning skills, difficulty in adjusting to the pace of college work, inadequate examination system, excessive preoccupation with entertainment and bad company. First year students as main general causes of learning failures in college indicated:

- $\quad$ lack of determination in learning (84.6\% of respondents),

- $\quad$ inadequate preparation in high school $(76.9 \%)$,

- $\quad$ choosing wrong field of study (resulting in lack of interest) $-50 \%$ of students.

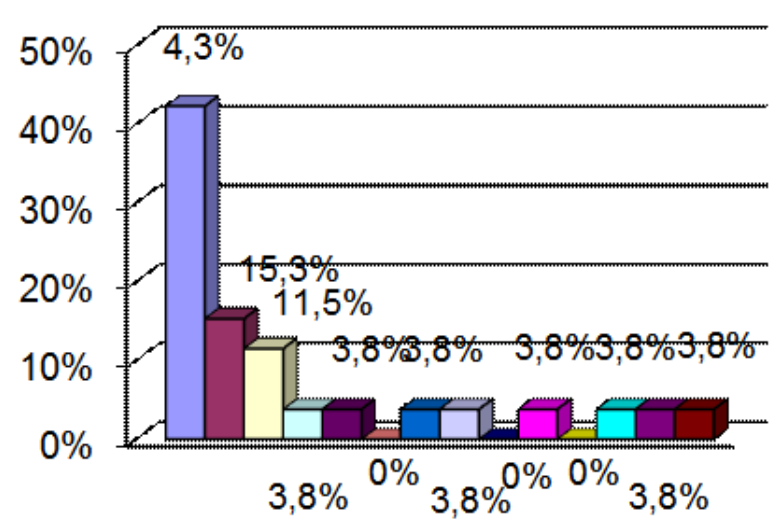

\begin{tabular}{|l|}
\hline 口low high school level \\
$\square$ wrong field of study \\
口Lack of conviction \\
$\square$ Material is sue \\
$\square$ Health problems \\
$\square$ mental breakdown \\
$\square$ lack of lea rning skills \\
$\square$ Educational lagging \\
$\square$ Lack of science books \\
$\square$ Too large material \\
$\square$ Not enough time for studing \\
$\square$ Wrong examination system \\
$\square$ Too many entertaiment \\
$\square$ others
\end{tabular}

Figure 1 Distribution of factors affecting learning failures at college in the opinion of first year TIE students of the Pedagogical University in Krakow 
Proceedings of the International Scientific Conference. Volume I, May $27^{\text {th }}-28^{\text {th }}$, 2016. 200-208

Table 1 Factors determining leaning failures in college in the opinion of first year TIE students of Pedagogical University in Cracow

\begin{tabular}{|l|l|l|l|l|}
\hline \multirow{2}{*}{ Reasons } & \multicolumn{3}{l}{ Generally } \\
\cline { 2 - 5 } & \multicolumn{2}{l}{ Pointed as the main } & \multicolumn{2}{l|}{ Pointed generally } \\
\cline { 2 - 6 } & Amount & \% & Amount & \% \\
\hline inadequate preparation in high school & 11 & 42,3 & 20 & 76,9 \\
\hline wrong field of study & 4 & 15,3 & 13 & 50 \\
\hline lack of dedication & 3 & 11,5 & 22 & 84,6 \\
\hline financial issues & 1 & 3,8 & 8 & 30,7 \\
\hline health problems & 1 & 3,8 & 7 & 26,9 \\
\hline mental breakdown & 0 & 0 & 7 & 26,9 \\
\hline lack of learning skills & 1 & 3,8 & 9 & 34,6 \\
\hline lag in education & 1 & 3,8 & 7 & 26,9 \\
\hline lack of science books & 0 & 0 & 3 & 11,5 \\
\hline too much to learn & 1 & 3,8 & 8 & 30,7 \\
\hline not enough time for studing & 0 & 0 & 9 & 34,6 \\
\hline wrong examination system & 1 & 3,8 & 2 & 7,6 \\
\hline too many entertaiment disruptions & 1 & 3,8 & 5 & 19,2 \\
\hline other & 1 & 3,8 & 1 & 3,8 \\
\hline
\end{tabular}

Third year ETI students indicated the same 3 most important factors, that can lead to failures at college, that were pointed by first year students. Distribution of third year students' answers is shown in the tab. 2. and fig. 2. The percentage distribution of failure factors indicated by older students:

- $\quad$ inadequate preparation at high school $-67.8 \%$,

- $\quad$ lack of motivation and persistence in learning $-50 \%$,

- choosing a wrong field of study (related to lack of interest in the learned subject) $-46.4 \%$. 
Henryk Noga, Jana Depešová, Aleksandra Knych. Causes of School Failures During Studies in the Opinion of Tie Students from the Pedagogical University of Cracow

Table 2 Factors influencing students' learning failures in the opinion of TIE third year students of the Pedagogical University in Cracow

\begin{tabular}{|l|l|l|l|l|}
\hline \multirow{2}{*}{ Reasons } & \multicolumn{3}{l}{ Generally } & \multicolumn{2}{l|}{ Pointed as the main } \\
\cline { 2 - 5 } & factor & \multicolumn{2}{l|}{ Pointed generally } \\
\cline { 2 - 6 } & Amount & \% & Amount & \% \\
\hline inadequate preparation in high school & 7 & 25 & 19 & 67,8 \\
\hline wrong field of study & 6 & 21,4 & 13 & 46,4 \\
\hline lack of dedication & 2 & 7,1 & 14 & 50 \\
\hline financial issues & 2 & 7,1 & 12 & 42,8 \\
\hline health problems & 1 & 3,6 & 10 & 35,7 \\
\hline mental breakdown & 2 & 7,1 & 12 & 42,8 \\
\hline lack of learning skills & 1 & 3,6 & 10 & 35,7 \\
\hline lag in education & 0 & 0 & 5 & 17,8 \\
\hline lack of science books & 0 & 0 & 7 & 25 \\
\hline too much to learn & 2 & 7,1 & 8 & 28,5 \\
\hline not enough time for studing & 1 & 3,6 & 7 & 25 \\
\hline wrong examination system & 1 & 3,6 & 6 & 21,4 \\
\hline too many entertaiment disruptions & 3 & 10,7 & 6 & 21,4 \\
\hline Other & 0 & 0 & 1 & 3,6 \\
\hline
\end{tabular}

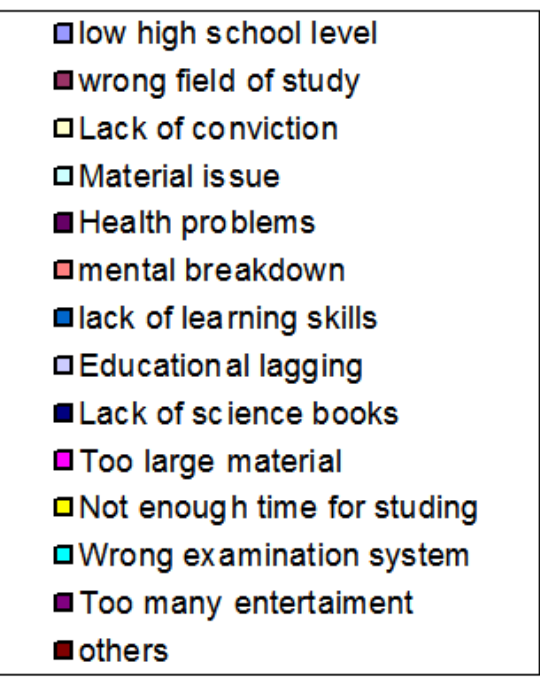

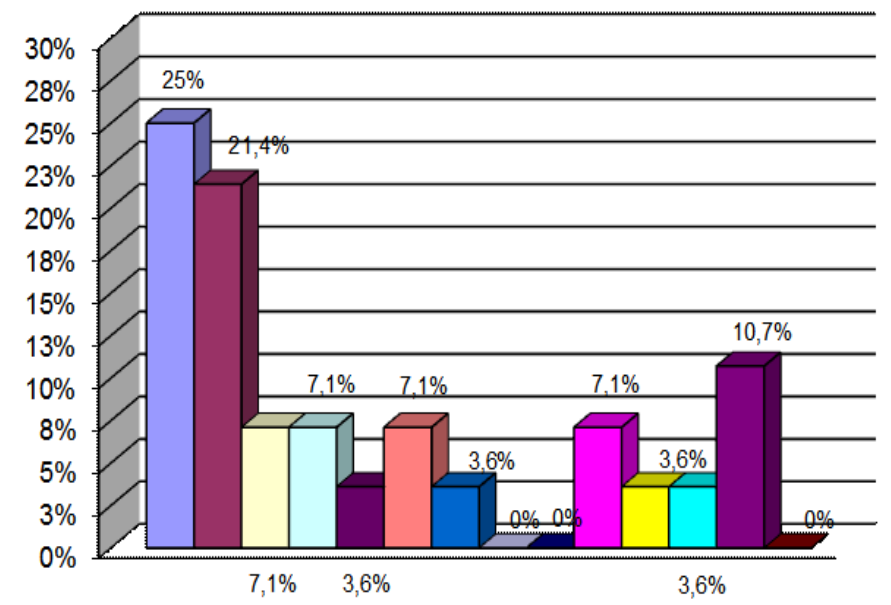

Figure 2 Percentage distribution of factors affecting learning failures as seen by third year TIE students of the Pedagogical University in Cracow 
The analysis of the answers shows that the most important factors that can result in learning problems and failures at collage are inadequate preparation in high school, lack of persistence in learning and wrong field of study. Most of the students causes of failures are seen in the teaching process as they point at too low level of teaching in high school. This element can be categorized as an pedagogical factor that cannot be controlled by the individual. Among college students, who emphasized the impact of high school in learning failures at collage 18 reported it as the most important factor, 39 as one of many. They argue that knowledge and skills gained at high school are not good enough base to succeed at university. Two other main causes pointed by students are related to the individual and lay within his control - lack of motivation and choosing the wrong field of study. These can be categorized as biological and psychological conditions.

Other biological and psychological factors that can result in learning failures according to third year students are:

- $\quad$ health problems $(35,7 \%)$,

- mental breakdown $(42,8 \%)$,

- $\quad$ lack of learning skills $(35,7 \%)$.

There is one more social factor that may influence learning performance in the opinion of third year students - financial problems (12\% of answers) and one more pedagogical factor - too much material to learn $(28,5 \%)$.

The presented analysis shows the most common causes of failure are the ones related to the intellectual and mental skills of the individual (fig. 1). These factors were indicated by $48.5 \%$ of students taking part in the study. Another group of causes are the bio-psychological. These were mentioned by $25.6 \%$ of TIE students of the Pedagogical University in Cracow. The third group of elements focuses on the reasons related with the organization of educational process at the university.

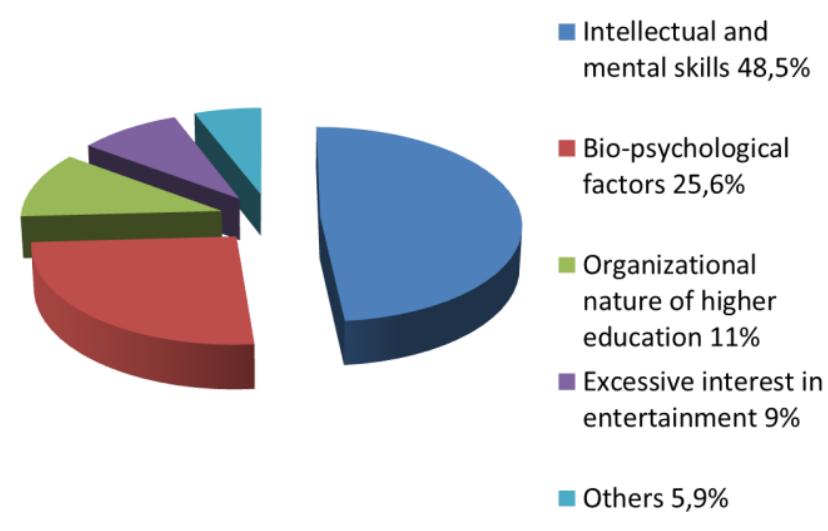

Figure 3 Analysis of most common causes of learning failures at college in the opinion of students of the Pedagogical University in Cracow 


\section{Conclusion}

School failures, which the European Union considers to be one of the greatest challenges for unifying Europe, has always belonged to the set of the most urgent issues to be analyzed and examined by the general didactics, which is by definition concerned with various aspects of educational effectiveness.

The changes connected with civilization as well as the changing educational approaches and constant educational failures in many countries make one reflect closely upon the conditioning of the phenomenon of failure, which seems to be connected not only to school activity but also with the activity of various educational institutions.

What seems to be essential when considering the problem of educational failure is the question of reasons for lack of success to occur. When one knows the source of failure, one can seek suitable solutions to eliminate it.

The authors who have analyzed the problem of school failures highlight the complexity of the reasons for difficulties students encounter at school, and have examined social, economic, biological, psychological and pedagogical factors. The question whether some of the factors are more important than others, remains open. Also, it has to be noticed that each case of school failure should be treated individually.

The research shows that the most important factors determining learning failures at collage in the opinion of students are: inadequate preparation at high school (pedagogical conditions, out of individual's control), lack of persistence and dedication and choosing a wrong field of study (the last two are related to the individual and are within his/her control).

\section{References}

Denek, K. (2002). Powodzenia i niepowodzenia szkolne w kontekście badań. Wychowanie na co dzień, 2002, nr 4 (5), 15-19.

DeMarie, D., \& Aloise-Young, P. A. (2003). College students' interest in their major. College Student Journal, 37 (3), 462-469.

Jankowska, D. (2014). Efektywność/efektowność edukacji akademickiej - pomiędzy pragmatycznością a upozorowaniem. In: Karpińska, A., Wróblewska, W. (eds.) Dydaktyka akademicka - wybrane obszary (pp 78-83). Warszawa: Wyd. Akademickie Żak.

Karpińska, A. (2010). Kontrowersje wokót pojęcia powodzeń i niepowodzeń szkolnych. Białystok: Wyd. Trans Humana.

Karpińska, A. (2011). Niepowodzenia edukacyjne - renesans myśli naukowej. Białystok: Wyd. Trans Humana.

Knych, A. (2015). Rozwijanie zainteresowań i uzdolnień uczniów ważnym zadaniem szkoły. W: Bánesz, G. (red.) Vzájomná informovanost' - cesta $k$ efektívnemu rozvoju vedecko- 
Proceedings of the International Scientific Conference. Volume I, May $27^{\text {th }}-28^{\text {th }}, 2016.200-208$

pedagogickej činnosti. Zborník z medzinárodnej konferencie doktorandov (pp 75-80). Nitra: Pedagogická Faculta UKF.

Kupisiewicz, Cz. (1995). Niepowodzenia dydaktyczne. Przyczyny i niektóre środki zaradcze. Gdańsk: Gdańskie Towarzystwo Psychologiczne.

Mastalerz, E., \& Gałązka, E. (2006). Inspiracje do aktywizujacej uczniów edukacji ogólnotechnicznej. Kraków: Wydawnictwo Uniwersytetu Pedagogicznego.

Niemierko, B. (2007). Kształcenie szkolne. Podręcznik skutecznej dydaktyki. Warszawa: Wyd. Akademickie i Profesjonalne.

Noddings, N. (2006). The Challenge to Care in Schools: An Alternative Approach to Education. New York: Teachers College Press.

Noga, H. (2015). O miejscu edukacji technicznej w systemie kształcenia. Konspekt, nr 1 (54), 20-23.

Noga, H. (2004). Przydatność do pracy absolwentów szkół zawodowych - doniesienia z badań. W: Furmanek, W., Walat, W. (red.) Technika-informatyka-edukacja (36-41). Rzeszów: Wyd, Fosze.

Prauzner, T., \& Ptak, P. (2014). Analiza parametrów pracy wybranych czujników pola magnetycznego. Przeglad Elektrotechniczny, nr 12 (14), 273-276.

Ptak, P., \& Prauzner, T. (2013). Badania czujników detekcji zagrożeń w systemach alarmowych. Przeglad Elektrotechniczny, $2013 \mathrm{nr} 10$ (13), 274-276.

Pytel, K., \& Jaracz, K. (2012). Analiza możliwości wykorzystania wybranych hybrydowych układów pozyskiwania energii ze źródeł odnawialnych. Przeglad Elektrotechniczny, nr 9 (12), 243-249.

Pytel, K. (2011). Analiza dostępności i niezawodności dużej elektrowni wiatrowej w wybranych lokalizacjach w Polsce, Journal of KONBiN, 20 (1), 29-36. 